○伊藤智史、布施健生、鈴木 豊、渡辺知緒、大竹祐輔、横田雅司、青柳 優 (山形大学医学部耳鼻咽喉科)、稲村和俊（山形県立新庄病院耳鼻咽喉科）

【はじめに】

急性感音性難聴は発症後に聴力が固定するまで数ヶ月を要し、治療の時点ではなかなか 聴力の長期予後は推定しにくい。今回我々は急性感音性難聴の症例において聴力の改善率 の経過を調べ、治療後の早期の時点で聴力の長期予後の推定が可能であるかを検討した.

\title{
【対象と方法】
}

平成 7 年 4 月から平成 12 年 3 月に山形大学医学部附属病院及び関連病院の耳鼻咽喉 科において入院の上加療した一側性急性感音性難聴患者 88 名 (平均年齢 52.8 歳、女性 : 男性=49:39) を対象とした。

治療法は、平成 9 年 11 月から平成 12 年 3 月までの間は、水溶性プレドニンの $60 \mathrm{mg} /$ 日よりの漸減投与とプロスタグランディン E1 (PGE1) の点滴 $(120 \mu \mathrm{g} /$ 日) の併用であ り、それ以外の期間では水溶性プレドニンの $200 \mathrm{mg} /$ 日よりの漸減投与と PGE1 点滴の 併用であった。

気導聴力の 5 分法により治療前、治療後 1 週間、2 週間、 1 ケ月、 2 ケ月、 3 ヶ月の聴 力検查から改善率を求めた。聴力改善の経過から治療後の予後の推定が可能であるか、ま た水溶性プレドニンの $60 \mathrm{mg} /$ 日よりの漸減投与群と $200 \mathrm{mg} /$ 日よりの漸減投与群の治療 経過の違いにつき検討した。

\section{【結 果】}

1) ステロイド通常量投与群 $(\mathrm{n}=50)$ （図 1$)$

治療開始後 2 週間で、ほぼ二群に分けることが出来た。すなわち、改善率が $50 \%$ 以上の群 (A 群) と改善率が $50 \%$ 未満の群（B 群）に分けられた。治療開始後 1 ケ 月での善率をみると、 $A$ 群の改善率 $(93.3 \pm 31.7 \%)$ は B 群の改善率 $(25.3 \pm 18.2 \%)$ よりも有意に大きくなった $(p<0.01)$ 。すなわち、治療後 2 週間での改善率が $50 \%$ に満たない群は、長期予後として見ても改善率は $50 \%$ に満たない例がほとんどであ った。

2) ステロイド大量投与群 $(n=38)$ （図 2$)$

治療開始後 1 2 週間での改善率が $50 \%$ を越える群（C群）と改善率が $50 \%$ に満 たない群（D群）に、ステロイド通常量投与群と比べ明確に分かれた。治療開始後 1 ケ月で、C 群の改善率 $(94.8 \pm 31.9 \%)$ は D 群の改善率 $(26.1 \pm 22.3 \%)$ よりも 有意に大きくなっており $(p<0.01)$ 、ステロイド通常量投与の場合と同様の結果で あった。 


\section{【考 察】}

ステロイド通常量投与群とステロイド大量投与群では共に治療開始 1〜2 週間後での改 善率が $50 \%$ を越える症例が、治療開始後 1 ケ月以降の聴力の長期予後は良かった。すな わち治療開始後 1 2 週間での改善率が、急性感音性難聴の長期予後を推測する上で重要 な因子であると考えられた。

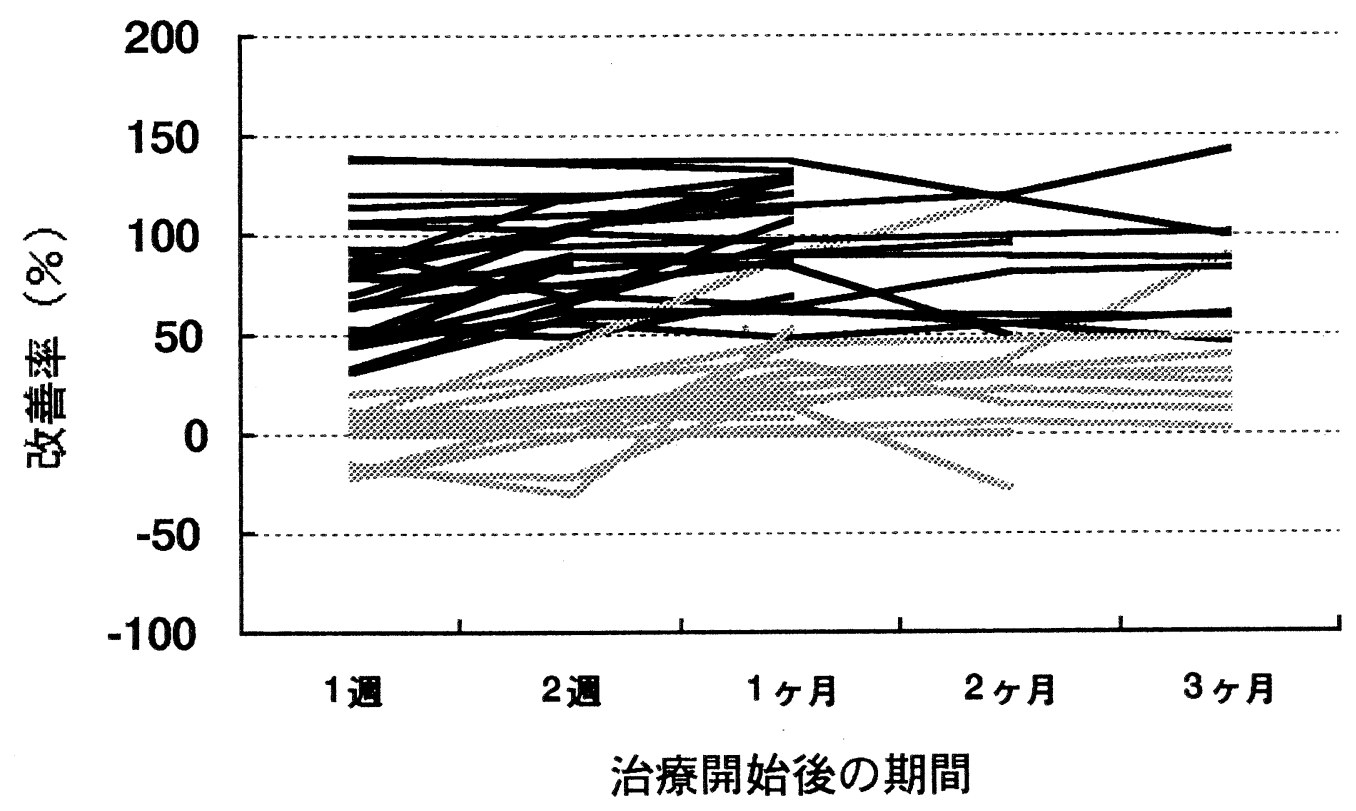

図 1 ステロイド通常量投与群での改善率の時間経過

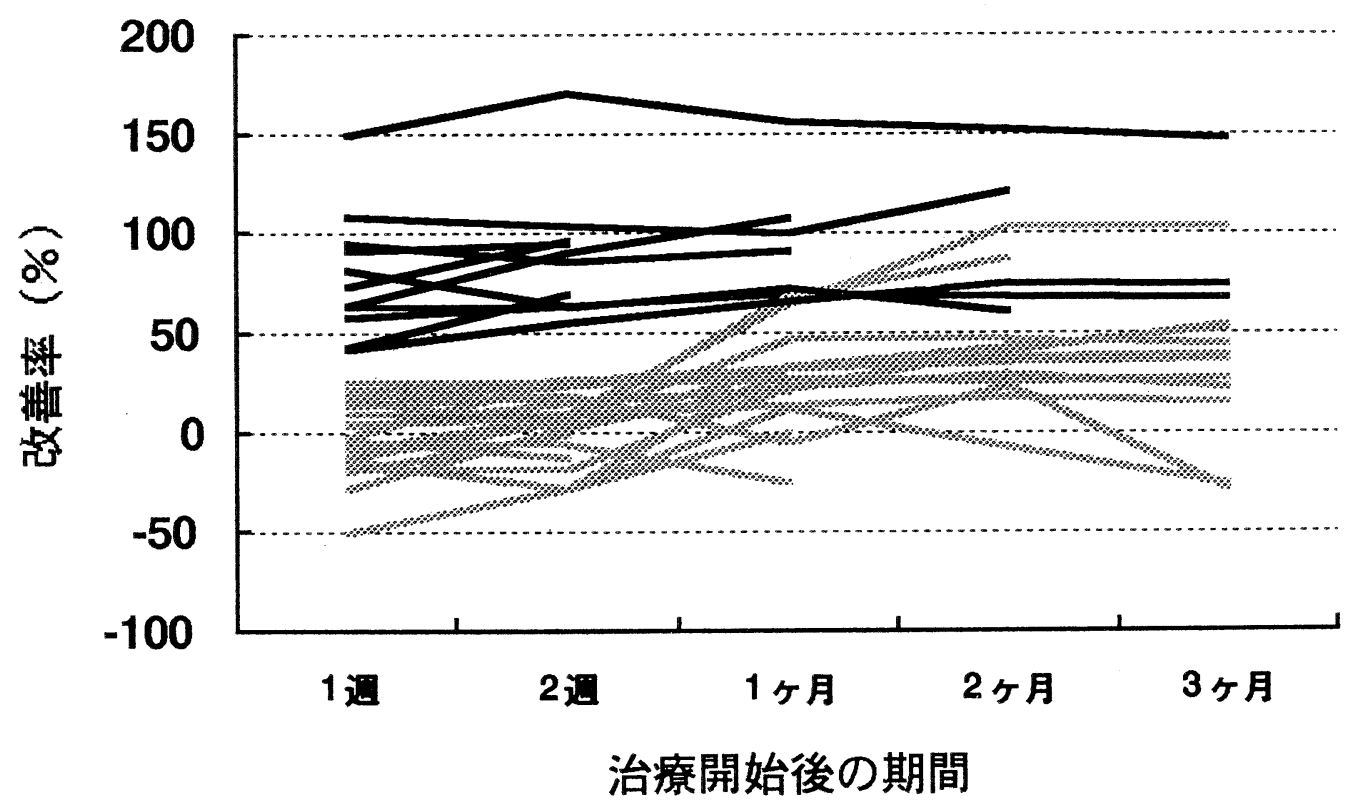

図 2 ステロイド大量投与群での改善率の時間経過 